\title{
The effects of job satisfaction, employee commitment, workplace friendship and team culture on service recovery performance
}

\author{
Abednego Feehi Okoe ${ }^{a}$, Henry Boateng ${ }^{b *}$ and Tiniwah Deborah Mensah ${ }^{a}$
}

${ }^{a}$ Department of Marketing, University of Professional Studies, Accra, Ghana ${ }^{b}$ Department of Marketing and Entrepreneurship, University of Ghana, Ghana

\section{H R O N I C L E}

Article history:

Received January 5, 2016

Received in revised format August 2, 2016

Accepted September 27, 2016

Available online

September 28, 2016

Keywords:

Job Satisfaction

Employee Commitment

Workplace Friendship

\begin{abstract}
A B S T R A C T
The existing literature has called for more studies to be conducted on how human resource activities affect service recovery performance. This study therefore ascertains the effects of Job Satisfaction, employee Commitment, Workplace Friendship and Team Culture on Service Recovery Performance. The survey research design was used in this study. The participants were frontline employees from the various service sectors in Ghana. The convenience sampling was used as the sampling technique. A total of 372 responses were used in the final analysis. The scale items were adapted from the existing literature. Confirmatory factor analysis was used to assess the fit of the model. Multiple linear regression was used to test the hypotheses. The findings indicate that Job Satisfaction, Employee Commitment, Workplace Friendship and Team Culture significantly exerts positive influence on Service Recovery Performance of frontline employees. The findings from the study imply that there are several antecedents to Service Recovery Performance. Team Culture, Workplace Commitment, and Employee Commitment can influence Job Satisfaction which in turn will affect Service Recovery Performance resulting in customer satisfaction and retention.
\end{abstract}

C) 2016 Growing Science Ltd. All rights reserved.

\section{Introduction}

The contribution of the services sector to the Gross Domestic Product (GPD) of economies of the world cannot be underestimated. The service sector offers employment to a greater number of people globally. In spite of this, the service sector continues to face difficulties in satisfying customers or meeting the expectations of customers. There are always delays in delivery, informational failure, rudeness on the part of staff, response failure etc. (Singhal et al., 2013). Most of the time these failures are caused by frontline staff who are arguably least paid by service organizations. Furthermore, when service failure occurs, the same frontline staff are expected to resolve the problem. The successful resolution of service failures can create a competitive advantage for service firms and lead to customer loyalty (Hinson, 2012). Darby (1999) noted that front line staff influences formation of customers' expectations and

* Corresponding author.

E-mail address: hboateng85@gmail.com (H. Boating) 
experiences to the extent that they are inseparable from the actual service. This suggests that the performance of frontline employees in service delivery and recovering service failure is very essential for service firms. Consequently, the need to investigate the workplace practices that have the potential of motivating service firms' employees to successfully recover service failure is relevant (Karatepe \& Vatankhah, 2015). Human resource management outcomes that are performance driven are key to ensure service recovery performance (Davidson et al., 2011). The existing literature has shown that human resource management outcomes such as selective staffing, teamwork, empowerment and training drive employees to meet job requirements and performance (Solnet et al., 2010). Similarly, Ng et al. (2011) noted that job satisfaction drives job performance. Again, Karatepe and Vatankhah (2015) found career opportunities, rewards, selective staffing, empowerment, teamwork, job security and training as the key performance-driven factors affecting service recovery performance in the airline industry. In this view, it can be argued that human resource activities and workplace activities can improve service recovery performance.

From the extant literature, it appears studies on the effects of job satisfaction, employee commitment, workplace place friendship and team culture on service recovery performance are very minimal. However, these are key components of human resource activities that influence employee performance (Hinson \& Kuada, 2014). Again, it appears that service recovery performance has received limited attention from scholars in developing countries like Ghana (Boateng \& Agyemang, 2015). Meanwhile, human resource activities such as team culture and job satisfaction can be context dependent (Katzell et al., 1992). In view of this gap in literature, this current study investigates the effect of employee commitment, job satisfaction, workplace friendship and team culture on service recovery performance of frontline employees in service organizations in Ghana. The rest of the paper is divided into five sections. Section one presents literature review and hypotheses while section two captures the methodology employed. Section three focuses on findings of the study while section four presents discussions and conclusions. The last section focuses on the implications of the study.

\section{Literature review and development of hypotheses}

\subsection{Service Recovery Performance}

According to Zemke and Schaaf (1990) the word "recovery" within a service context was derived from British Airway's "putting the customer first" campaign. Service recovery is defined as a firm's attempt to overcome the negative effect of a failure or breakdown. In recent times, Zeithaml et al. (2010 p. 213) have defined service recovery as "actions taken by an organization in response to a service failure". The importance of service recovery is well documented in the marketing literature. Zeithaml and Bitner (2000) believe that while it is not possible for organizations to prevent all problems, they can, at least, try to recover from them. As far back as 1992, Berry and Parasuraman posited that firms should consider failure as an opportunity to satisfy customers better rather than a problem that creates dissatisfied customers. Heskett et al. (1990) referred to service organizations that provide effective response to service failures as "breakthrough" organizations. Such firms, according to Hinson and Kuada (2014) will reap success in the long-term. It is therefore critical that organizations pay attention to service recovery performance of employees. Liao (2007) defined employee service recovery performance (SRP) as "the behaviors in which customer service employees who directly handle customer complaints engage to recover customer satisfaction and loyalty after service failures." He identified three key features of SRP. First, SRP should focus on frontline employees who should be seen as boundary spanners for the service firm. Although boundary spanners may not necessarily be responsible for the service failures, most of the recovery activities fall within the prerogative of frontline employees. Second, SRP refers to specific types of employee behaviors and should be distinguished from its results. SRP refers to the words and actions of the employees in handling customer complaints. On the other hand, results of SRP focuses on how SRP influences customer perceptual, affective and behavioral intentions such as customer satisfaction and repurchase intentions. Third, SRP is a multidimensional construct. Previous studies have investigated various types of service 
recovery efforts after service failures including apology, empathy, explanation, compensation, repair, replacement, and refund (Sparks \& McColl-Kennedy, 2001; Zeithaml et al., 2009; Hinson, 2012; Hinson \& Kuada, 2014). This study conceptualizes service recovery performance as the words and behaviors of frontline service employees aimed at resolving customer complaints as a result of service failures with the ultimate aim of recovering the service and thereby ensuring customer satisfaction and retention.

\subsection{Employee Commitment and Service Recovery Performance}

Boshoff and Allen (2000) investigated the potential impact of organizational variables on frontline service recovery performance. They hypothesized that job perceptions and employee attitudes have a major impact on frontline staff service recovery performance. Three factors were identified as being directly affected by employee attitudes and which consequently influence a firm's SRP and these include employee commitment to service excellence, an organization's customer service orientation and employee rewards for service excellence. Jenkins et al. (1982) postulated that the lack of employee commitment accounts for poor quality improvement efforts. Employee commitment is believed to be a function of top management commitment. In other words, lack of commitment on the part of management to the objective of service excellence, is directly proportionate to employee commitment to service recovery performance. Branson (1991) identified managerial actions as the most important variable in influencing employee behavior. By implication therefore managers are expected to lead from the front and demonstrate the behavior they require of employees. While it is acknowledged that top management usually places a distance between them and frontline staff, it is still prudent for management to demonstrate strong commitment to service excellence, if employees are to emulate their example. Zeithaml et al. (2009) supported this view and indicated that unless management are fully committed to SRP, the desired objective would not be achieved. However, studies on the relationship between employee commitment and performance indicate mixed results. Boshoff and Allen (2000) believed that the inconsistencies could be attributed to the measurement of different types of commitment. In spite of these disagreements, recent studies have shown that, in a service environment, employee commitment positively influence service quality, as they tend to dedicate more time, more energy and more of their skills and talents to the firm for which they are employed compared to their uncommitted counterparts (Liao, 2007). The study therefore hypothesizes that;

$\mathrm{H}_{1}$ : A high level of employee commitment towards the service organization will pose a favorable influence on SRP.

\subsection{Job Satisfaction and Service Recovery Performance}

For several decades, the link between job satisfaction and performance has received a lot of scholarly attentions. As far back as the 1920s, the Hawthorne Studies were among the pacesetters in the empirical investigation of this relationship (Katzell et al. 1992). In spite of the plethora of literature on the subject, the debate is still alive with regards to the nature and causal direction of the relationship (Boshoff \& Allen, 2000). The popular proposition (especially among practitioners) held is that satisfied employees outperform the dissatisfied ones. Several empirical studies, however have demonstrated a weak relationship between the two variables (Hess Jr. et al., 2003; McCollough et al., 2000). Evidence also exists pointing to the fact that, rather, employees who do well enjoy their jobs. In service oriented firms, according to Hinson (2012), job satisfaction drives customer-oriented behavior. This finding is supported by the view that providers derive both extrinsically (in the form of financial benefits) and intrinsically (job satisfaction) as a result of satisfaction of the customer. Also, service providers who are in a happy mood are more likely to engage in prosocial behavior. Further, Zeithaml et al. (2009) suggested that people in a happy mood are more likely to offer help and be considerate. The findings are subsequently linked to job satisfaction indicating that satisfied employees are more prone to be in a happy mood and therefore more disposed to behaving in a considerate manner towards others. Roger et al. (1994) earlier pointed out that it is highly unlikely for boundary spanning employees to deliver superlative service when they are unhappy in their work. Their conclusion that there exists a positive 
relationship between job satisfaction and good customer care has however been proved to be weak, empirically. Bagozzi (1980) argued it is rather easier for service performance to cause job satisfaction as employees compare expected intrinsic and extrinsic rewards with the actual rewards received and forms favorable or unfavorable emotions. On the contrary, he believed that it is more difficult to justify the link between job satisfaction and performance. Despite this assertion, this study takes the conventional view and models SRP as an outcome of job satisfaction. Therefore, this study hypothesizes that;

$\mathrm{H}_{2}$ : Employee job satisfaction will pose a favorable influence on service recovery performance.

\subsection{Workplace Friendship and Service Recovery Performance}

The concept of workplace friendship still faces definitional problems. Lin (2010) defines workplace friendship as "the close human relationship that employees who work in an organization build up". Earlier, Song (2006) took inspiration from Hays (1988) and Jehn and Shah (1997) and defined workplace friendship as "a voluntary interdependent relationship in the workplace between two persons to facilitate social-emotional goals of the participants with different types or degrees of intimacy, companionship, mutual assistance and amiable relationship." While acknowledging the plethora of definitions, it is clear that workplace friendship can either hinder or help the formal organizational goals (Nielsen et al., 2000) including service recovery performance.

Majority of adult people spend a large part of their lives at work and therefore friendship between coworkers usually foster. Such friendship may be linked to critical work-related performances including organizational commitment, job involvement and job satisfaction (Riordan \& Griffeth, 1995). Workplace friendship is found to benefit both the individual worker and the organization (Rawlins, 1992). From the individual standpoint, workplace friendship provides emotional advantages (Kram \& Isabella, 1985), improved job performance (Zetlin, 1991), enhanced career development and working environment (Yager, 1997). From the firm's viewpoint, favorable outcome can result from favorable workplace friendship (Morrison, 2004; Jehn \& Shah, 1997) including encouraging employee retention (Riordan \& Grifeth, 1995), organizational productivity and institutional capacity (Crabtree, 2004; Ellingwood, 2001)

In spite of these favorable impact of workplace friendship, Song (2006) identified several reasons why these positive effects have been overlooked. These were listed as the negative effects of workplace including gossip, sexual harassment, fleeting loyalty to the organization, favoritism and organizational politics. Sias et al. (2004) argued that despite the negative impact of workplace friendship, the subject is still important, not just because of its benefits to both the individual and the firm, but more importantly because of its association with job performance. By implication, workplace friendship is expected to correlate with service recovery performance.

Many reasons have been adduced for the study of work place friendship (Nielsen et al., 2000). The key reason is the relationship between workplace performance and work-related performance. According to Riordan and Griffeth (1995), there is a positive correlation between friendship, job satisfaction and performance resulting in less employee job turnover. Neilson et al. (2000) also found a close relationship between workplace friendship and organizational performance. Indeed, workplace friendship is considered a significant factor in the study of employee relationship in the workplace (Lin, 2010). It is still debatable whether workplace friendship influences job performance or the other way round as mixed results have been produced (Nielsen et al., 2000; Lin, 2010). This study hypothesizes that:

$\mathrm{H}_{3}$ : Workplace friendship positively influences service recovery performance.

\subsection{Team Culture and Service Recovery Performance}

According to Boshoff and Allen (2000), the everyday working environment in which employees function heavily influences their behavior and performance. One of the variables that moderate job 
performance is the role of knowledge sharing within a team. Team work has been found to impact job performance in a positive way within several environments (Andrews, 1995). While it cannot be denied that superlative service will result periodically from the initiative of one person, it is usually as the result of the activities of several people working together (Berry, 1995) Ultimately, the boundary spanners (frontline staff) are responsible for interfacing with customers, but the full support of the backroom staff is required to ensure a smooth service encounter situation.

Zeithaml et al. (2009) explained that customers were only exposed to a limited part of the service delivery process (banking services, for example). While not every employee of the organization deals directly with end users, each task is vitally important in ensuring service excellence (Lovelock \& Wrtiz 2004). Each employee serves a particular customer, whether internal customer (a fellow employee) or an external one (end users). Once employees understand that each of them serves a customer and accountable to them, the task they perform becomes more meaningful.

An effective team culture glues employees together and motivates team members to contribute for the common good. As Berry (1995) pointed out, the team culture should help support and motivate members to share knowledge and appreciate the contributions of each individual in the achievement of primary objectives. The management and services marketing literature provide evidence that knowledge sharing in teamwork promotes performance (Kuada \& Hinson, 2012). The study hypothesized that:

$\mathrm{H}_{4}$ : Teamwork culture will influence employee SRP through the moderating role of knowledge sharing

\section{Methodology}

\subsection{Overview of the Service Sector and Service Failure in Ghana}

Ghana's services sector is reported to be the leading contributor to Gross Domestic Product (GDP). According to Ghana Statistical Service Report (2014), the services sector contributed more than 50\% of GDP, with manufacturing and agriculture recording a distant $28.57 \%$ and $22.0 \%$ respectively. Thus, the services sector's contribution to the economy of Ghana totals the contributions of all the other sectors combined. The report indicated that the service sector exceeded its 2012 target of $7.7 \%$ by $1.1 \%$ points to register an impressive growth rate of $8.8 \%$. The major areas of growth included the Information and Communication sub sector (24.7\%), Finance and Insurance subsectors (23. 2\%), Hotels and Restaurants (13.6\%), Business Services (13. 5\%) and Transport and Storage (11.4\%). As Kotler and Keller (2006) indicated, the growth of the services sector serves as a good barometer for the development of a country.

Developed economies therefore tend to be more service-oriented compared to their developing country counterparts. On the employment front, Otoo et al. (2009) reported that the services sector in Ghana employs about $20 \%$ of the total workforce representing one-fifth of the working population. Thus, the relevance of the services sector cannot be underestimated and therefore serves as focal point for this research. In spite of the importance of services, the extant literature on service failure and recovery suggests that a majority of the studies were conducted in developed countries (Amankwah-Amoah \& Debrah, 2010). Nevertheless, the scanty literature on the subject of service failure in Ghana indicates service failure remains critical in the demise of most organizations in Ghana.

\subsection{Research Design and Sampling Design}

This study used the survey research design. This was to enable the collection of large data and generalize the findings to the entire population. They were selected from the service sectors in Ghana. In all 372 respondents were used in this study. The respondents of the study consisted of the frontline employees from the service sector who consistently interact with customers. The respondents were made of 58.9 females and $41.1 \%$ males. Most (49.6\%) of the respondents have worked for 1-3 years while 34.2\% have worked for 4-6 years. Additionally, $8.8 \%$ have worked for 7-9 years while 7.4 \% have worked for 10 years and above. The sample was selected using the convenience sampling 
technique. This decision was taken because of lack of sample frame. The sampling technique also made it easy for data collection as the participants were easily available.

\subsection{Measures}

The scale items for this study were all adapted from the extant literature. The scale items measuring Employee Commitment were derived from Chang and Chang (2009) while that of Job Satisfaction (JB) were adapted from Scarpello and Campbell (1983). Also, scale items measuring Workplace Friendship (WF) were borrowed from Neilsen et al. (2000); items measuring Team Culture were adapted from Stashevsky and Koslowsky (2006). SRP was measured using scale items from Boshoff and Allen (2000). Table 1 contains all the items that were used to measure the constructs. All the items were measured on a five-point likert scale; $1=$ strongly disagree, $2=$ disagree, $3=$ neutral, $4=$ agree and $5=$ strongly agree. This was to avoid ambiguity in the scale.

\section{Table 1}

Cronbach's alphas $(\alpha)$, composite reliability (CR), Average Variance Extracted (AVE) and factor loadings

\begin{tabular}{|c|c|}
\hline $\begin{array}{l}\text { Constructs/Items } \\
\text { Employee Commitment } \quad \mathrm{CR}=.83 ; \mathrm{AVE}=.52\end{array}$ & Loadings \\
\hline I care about the future development of this company & 0.70 \\
\hline I feel I have a promising future if I stay with this company & 0.74 \\
\hline I will pass on my working experience to new staff & 0.69 \\
\hline I am emotionally attached to this company & 0.69 \\
\hline $\begin{array}{ll}\text { Job Satisfaction } & \mathrm{CR}=.87 ; \mathrm{AVE}=.52 \\
\end{array}$ & \\
\hline I am satisfied with the freedom to use my own judgment & 0.63 \\
\hline I am satisfied to try my own methods of doing the job & 0.60 \\
\hline I am satisfied with the way my co-workers get along with each other & 0.69 \\
\hline I am satisfied with the way my job provides for steady employment & 0.76 \\
\hline I am satisfied with the way the company policies are put into practice. & 0.74 \\
\hline I am satisfied with the working conditions of my company & 0.71 \\
\hline Workplace Friendship $\quad \mathrm{CR}=.79 ; \mathrm{AVE}=.50$ & \\
\hline I have the opportunity to get to know my co-workers & 0.67 \\
\hline I am able to work with my co-workers to collectively solve problems & 0.76 \\
\hline Communication among employees is encouraged by my organization & 0.76 \\
\hline I have formed strong friendships at work & 0.60 \\
\hline Team Culture $\quad \mathrm{CR}=.90 ; \mathrm{AVE}=.60$ & \\
\hline In my organization, there is always someone to address work problems & 0.69 \\
\hline My team supports knowledge and technical information sharing & 0.79 \\
\hline This company coordinates teamwork through team leaders & 0.74 \\
\hline This company's employees are flexible about meeting to discuss problems and coordinate teamwork & 0.76 \\
\hline This company teams possess a fine spirit & 0.73 \\
\hline Members of this team have a sense of participation & 0.73 \\
\hline Service Recovery Performance $\quad \mathrm{CR}=.85 ; \mathrm{AVE}=.53$ & \\
\hline Considering all the things I do, I handle dissatisfied customers quite well & 0.70 \\
\hline I don't mind dealing with complaining customers & 0.73 \\
\hline No customer I deal with leaves with problems unresolved & 0.75 \\
\hline Satisfying complaining customers is a great thrill to me & 0.74 \\
\hline Complaining customers I have dealt with in the past are among today's most loyal customers & 0.70 \\
\hline
\end{tabular}

\subsection{Reliability and Validity of Constructs}

The reliability and validity of the constructs were measured using the factor loadings, average variance extracted (AVE), discriminant validity and composite reliability. As shown in Table 1 the factor loadings were all high and there were no cross loadings. Furthermore, the composite validity values for all the constructs were above the recommended threshold of 0.6 (Hair et al., 2006). Additionally, the squared correlations of the constructs were less than the AVEs (see Table 2). This indicates that convergent validity and discriminant validity have been achieved (Bagozzi \& Yi, 2012). 
Table 2

Squared correlations and AVEs

\begin{tabular}{llllll}
\hline Constructs & EC & JS & WF & TC & SRP \\
\hline Employee Commitment (EC) & $\mathbf{. 5 2}$ & & & & \\
Job Satisfaction (JS) & 0.42 & $\mathbf{. 5 2}$ & & & \\
Workplace Friendship(WF) & 0.32 & 0.31 & $\mathbf{. 5 0}$ & & \\
Team Culture (TC) & 0.32 & 0.42 & 0.32 & $\mathbf{. 6 0}$ & $\mathbf{. 5 3}$ \\
Service Recovery Performance (SRP) & 0.39 & 0.24 & $\mathbf{0 . 4 9}$ & 0.38 & \\
\hline
\end{tabular}

Note: Diagonal variables are the AVE values

\section{Results}

The study used multiple linear regression analysis to predict employees' service recovery performance from job performance, employee commitment, workplace friendship and team culture. This method has been found to be a robust method for predicting an outcome from two or more predictor variables (Hair et al., 2006). All the predictor variables were significant (see Table 3). Employee commitment made the highest $(\beta=.168)$ contribution to the model followed by team culture $(\beta=.152)$. Furthermore, workplace friendship made the third highest contribution $(\beta=.145)$ while job satisfaction made the least $(\beta=.144)$ (see table 4).

Table 3

Model fit

\begin{tabular}{llllll}
\hline Model & R & R Square & Adjusted R Square & Std. Error of the Estimate & Sig. \\
\hline 1 & $.693^{\mathrm{b}}$ & .480 & .472 & & .000
\end{tabular}

Predictors: Employee commitment, Job Satisfaction, Workplace Friendship, Team Culture

Table 4

ANOVA $^{\mathrm{c}}$

\begin{tabular}{llrrrr}
\hline Model & & Sum of Squares & df & F & Sig. \\
\hline \multirow{2}{*}{1} & Regression & 112.227 & 6 & 56.359 & $.000^{\mathrm{b}}$ \\
& Residual & 121.469 & 366 & & \\
\cline { 2 - 6 } & Total & 233.696 & 372 & & \\
\hline
\end{tabular}

Predictors: Employee commitment, Job Satisfaction, Workplace Friendship, Team Culture

Dependent Variable: Service Recovery Performance

The results suggest that employee commitment explains $17 \%$ of the variance in employee service recovery performance while team culture explains $15 \%$. Similarly, workplace friendship explains $15 \%$ of the variance in employee service recovery performance while job satisfaction explains $14 \%$ of the variance in employee service recovery performance. The four predictor model accounted for $47 \%$ of the variance in service recovery performance, $F(6,366)=56.359, p<.001, R^{2}=.47($ see Table 5$)$.

Table 5

Coefficients $^{\mathrm{a}}$

\begin{tabular}{llrrrrr}
\hline Model & & Unstandardized Coefficients & Standardized Coefficients & $\mathrm{t}$ & Sig. \\
& & $\mathrm{B}$ & $\mathrm{Std}$. Error & Beta & & \\
\hline & Employee commitment & .170 & .052 & .168 & 3.260 & .001 \\
& Job Satisfaction & .144 & .056 & .144 & 2.388 & .011 \\
& Workplace Friendship & .175 & .067 & .145 & 2.606 & .010 \\
& Team Culture & .155 & .062 & .152 & 2.490 & .013 \\
\hline
\end{tabular}

a. Dependent Variable: Service Recovery Performance

\section{Discussions and conclusions}

The objective of this study was to assess the antecedents of Service Recovery Performance (SRP). The study found employee commitment, job satisfaction, team culture and workplace friendship as essential factors for service recovery performance. Satisfying dissatisfied customers will require commitment from employees; it will require employees who care about the future development of the company and are willing to serve the company. Additionally, employees who are emotionally attached to companies are able to satisfy complaining customers by putting in much effort to ensure that they resolve their 
problems. Furthermore, the study noted that in order for employees to recover service failure and satisfy dissatisfied customers, the employees themselves must first be satisfied. They tend to do better in service recovery when they are given the freedom to use their own discretion to resolve customers' complaints. Additionally, resolving customers' complaints and turning them to loyal customers will require employees who are satisfied with the working conditions of their companies. This finding is consistent with Boshoff and Allen (2000) who noted that employee commitment has a significant effect on service recovery performance. Employees who found themselves in an enabling working environment tend to perform; they give their best because they are assured of steady employment (Karatepe \& Vatankhah, 2015). Furthermore, the findings of this study corroborates that of Andrews' (1995) observation that team culture is a key determinant of service recovery performance. This is probably because when employees work in teams, there are always people around to discuss and resolve customers' problems. Again team culture has effect on service recovery performance probably because members of the team have a sense of participation and possess a fine spirit which encourages members to help each other to resolve problems.

In addition, the study found workplace friendship as determinant of service recovery performance. Employees having the opportunity to get to know each other, encourages free flow of information. This enables employees to acquire knowledge from colleagues which help them to deal with customer complaints (Yager, 1997). However, workplace friendship might not necessarily lead to service recovery performance; it should be backed by the willingness of the "friends" to share their professional and personal experiences. Again, they should be willing to share new methodology for performing task and valuable knowledge with others. This can be achieved by promoting socialization among employees (Neilsen et al., 2000). Employees' socialization can influence them to express their opinions and ideas towards during company's meetings. Finally, this study found that job satisfaction has a significant and positive effect on service recovery performance. This is not surprising as Hinson (2012) noted that job satisfaction drives customer-oriented behavior. This suggests that for employees to recover service failure successfully, the right working conditions must be created and communicated to them. This will involve creating a cordial relationship among employees and developing policies that offer steady employment to employees. An important finding from this study is establishment of causality between the other factors and Service Recovery Performance which was not clearly established in other studies (Nielson et al., 2000; Boshoff \& Allen, 2000)

\section{Implications of the study}

The implications of these findings are that, first, employees must be made to feel that they have a promising future in the organization; they can attain a position they are aspiring for. Employees must be satisfied before they can also satisfy the customers. The cliché that satisfied customers are more likely to be retained applies to employees as well. In other words, satisfied employees are more likely to be retained which positively correlates with customer retention. This will mean that organizations need to practice internal marketing. Organization need to identify the needs and wants of employees and satisfy them.

Second, organizations must encourage teamwork or team culture by giving tasks that demand efforts from different employees within the organization. Team culture can be promoted by rewarding teams instead of individuals. The general notion is that employees who get along well tend to work well

together. Firms must therefore purposely select team members on the basis of their compatibility and possessing the necessary traits required in team relations.

Third, workplace friendship should be encouraged in organizations. Employees should be made to see each other as a true friend. However, workplace friendship for its own sake will not necessarily promote service recovery performance. Organizations should gear workplace friendship towards meeting organizational goals. Organizing social events and creating an environment where families of employees regularly meet can promote friendship among them. Practical examples include the establishment of schools and other social amenities for employees and their families. Indeed, workplace 
friendship can help create effective teams and promote job satisfaction resulting in positive service recovery performance.

One of the limitations of the study is that it employed a convenience sampling technique which makes it difficult for the findings to be generalized. Generalization of the findings must therefore be done cautiously. Future studies may employ a probability sampling technique to address this limitation. Again, future studies should explore other human resource activities that improves service recovery performance. Furthermore, future studies may assess service recovery performance from customers' perspectives since in reality the employee are likely to be bias in assess their performance.

\section{References}

Andrews, K. Z. (1995). Cross-functional teams. Harvard Business Review,73(6), 12-13.

Amankwah-Amoah, J., \& Debrah, Y. A. (2010). The protracted collapse of Ghana Airways: Lessons in organizational failure. Group \& Organization Management, 35(5), 636-665.

Bagozzi, R. P. (1980). Performance and satisfaction in an industrial sales force: An examination of their antecedents and simultaneity. The Journal of Marketing, 44(2), 65-77.

Bagozzi, R. P., \& Yi, Y. (2012). Specification, evaluation, and interpretation of structural equation models. Journal of the Academy of Marketing Science, 40(1), 8-34.

Berry, L. L., \& Parasuraman, A. (1992). Prescriptions for a service quality revolution in America. Organizational Dynamics, 20(4), 5-15.

Berry, L. L. (1995). Relationship marketing of services - growing interest, emerging perspectives. Journal of the Academy of Marketing Science, 23(4), 236-245.

Boateng, H., \& Agyemang, F. G. (2015). The effects of knowledge sharing and knowledge application on service recovery performance. Business Information Review, 32(2), 119-126.

Boshoff, C., \& Allen, J. (2000). The influence of selected antecedents on frontline staff's perceptions of service recovery performance. International Journal of Service Industry Management, 11(1), 63-90.

Branson, R. K. (1991), Instructional systems development in the military and industry, Englewood Cliffs, NJ: Educational Technology Publications.

Chang, C. S., \& Chang, H. H. (2007). Effects of internal marketing on nurse job satisfaction and organizational commitment: example of medical centers in Southern Taiwan. Journal of Nursing Research, 15(4), 265-274.

Crabtree, S. (2004). Getting personal in the workplace: Are negative relationships squelching productivity in your company. Gallup Management Journal, June ,1-4.

Darby, D. N., \& Daniel, K. (1999). Factors that influence nurses' customer orientation. Journal of Nursing Management, 7(5), 271-280.

Davidson, W. R., Brown, J. H., Burnside, A. D., DeLong, J. P., Dunn, W. C., Hamilton, M. J., and Zuo, W. (2011). Energetic limits to economic growth. BioScience, 61(1), 19-26.

Ellingwood, S. (2001). The collective advantage: Contrary to popular belief, workplace friendships boosts profit. Gallup Management Journal, 1(3), 1-2.

Ghana Statistical Service (2013). Provisional Gross Domestic Product 2013. Available at: http://www.statsghana.gov.gh/cen surv.html, (Accessed 15 June 2015).

Hair, J. F., Black, W. C., Babin, B. J., Anderson, R. E., \& Tatham, R. L. (2006). Multivariate data analysis (Vol. 6). Upper Saddle River, NJ: Pearson Prentice Hall.

Hays, R. (1988). Friendship. In: Duck, S. (Ed.), Handbook of personal relationships, London: Wiley.

Heskett, J.L., Sasser, W.E. Jr., \& Hart, C.W.L. (1990). Service Breakthroughs: Changing the Rules of the Game, The Free Press, New York, NY

Hess, R. L., Ganesan, S., \& Klein, N. M. (2003). Service failure and recovery: The impact of relationship factors on customer satisfaction.Journal of the Academy of Marketing Science, 31(2), 127-145.

Hinson, R. E. (2012). Service Marketing Excellence with a twist of Corporate Social Responsibility, Accra: Sedco Publishing Limited.

Hinson, R. E., \& Kuada, J. (2014). Corporate social responsibility (CSR) practices of foreign and local companies in Ghana. Thunderbird International Business Review, 54(4), 521-536.

Jenkins, G. D., Shaw, J. D., Delery, J. E., \& Gupta, N. (1998). An organization-level analysis of voluntary and involuntary turnover. Academy of Management Journal, 41(5), 511-525. 
Jehn, K. A., \& Shah, P. P. (1997). Interpersonal relationships and task performance: An examination of mediation processes in friendship and acquaintance groups. Journal of Personality and Social Psychology, 72(4), 775-789

Karatepe, O. M., \& Vatankhah, S. (2015). High-performance work practices, career satisfaction, and service recovery performance: a study of flight attendants. Tourism Review, 70(1), 56-71.

Katzell, R. A., Thompson, D. E., \& Guzzo, R. A. (1992). How job satisfaction and job performance are and are not linked. Job satisfaction, pp. 195-217.

Kotler, P., \& Keller, K.L. (2006). Marketing Management, 12th ed., Prentice Hall, Upper Saddle River, NJ.

Kram, K. E., and Isabella, L. A. (1985). Mentoring alternatives: The role of peer relationships in career development. Academy of Management Journal, 28(1), 110-132.

Liao, H. (2007). Do it right this time: the role of employee service recovery performance in customer-perceived justice and customer loyalty after service failures. Journal of Applied Psychology, 9(2), 475-489

Lin, C. T. (2010). Relationship between job position, job attributes, and workplace friendship: Taiwan and China. Journal of Technology Management in China, 5(1), 55-68.

Lovelock, C.H., \& Wirtz, J. (2004). Services Marketing - People, Technology, Strategy, 5th ed., Prentice-Hall, Upper Saddle River, NJ.

McCollough, M. A., Berry, L. L., \& Yadav, M. S. (2000). An empirical investigation of customer satisfaction after service failure and recovery.Journal of service research, 3(2), 121-137.

Morrison, R. (2004). Informal Relationships in the Workplace: Associations with Job Satisfaction, Organisational Commitment and Turnover Intentions.New Zealand journal of psychology, 33(3), 114-128.

Nielsen, I. K., Jex, S. M., \& Adams, G. A. (2000). Development and validation of scores on a two-dimensional workplace friendship scale.Educational and Psychological Measurement, 60(4), 628-643.

Ng, S. I., Sambasivan, M., \& Zubaidah, S. (2011). Antecedents and outcomes of flight attendants' job satisfaction. Journal of Air Transport Management, 17(5), 309- 313

Otoo, Nyarko K., Boateng- Osei, C., \& Adjaye- Osei P. (2009). The Labour Market in Ghana. Labour Research and policy Institute, 1-52

Rawlins, W. K. (1992). Friendship matters: Communication, dialectics, and the life course, Transaction Publishers.

Riordan, C. M., \& Griffeth, R. W. (1995). The opportunity for friendship in the workplace: An underexplored construct. Journal of Business and Psychology, 10(2), 141-154.

Scarpello, V., \& Campbell, J. P. (1983). Job satisfaction: Are all the parts there?. Personnel Psychology, 36(3), 577-600.

Sias, P. M., Heath, R. G., Perry, T., Silva, D., \& Fix, B. (2004). Narratives of workplace friendship deterioration. Journal of Social and Personal Relationships, 21(3), 321-340.

Singhal, S., Krishna, A., \& Lazarus, D. (2013). Service failure magnitude and paradox: a banking perspective. Journal of Relationship Marketing, 12(3), 191-203.

Solnet, D., Schubert, F., Kandampully, J., \& Kralj, A. (2010). Exploring consumer perceptions of green restaurants in the US. Tourism and Hospitality Research, 10(4), 286-300.

Song, S. H. (2006). Workplace friendship and employees' productivity: LMX theory and the case of the Seoul city government. International Review of Public Administration, 11(1), 47-58.

Sparks, B. A., \& McColl-Kennedy, J. R. (2001). Justice strategy options for increased customer satisfaction in a services recovery setting. Journal of Business Research, 54(3), 209-218.

Stashevsky, S., \& Koslowsky, M. (2006). Leadership team cohesiveness and team performance. International Journal of Manpower, 27(1), 63-74.

Zeithaml,V.A. \& Bitner,M.J.(2000). Services Marketing. McGraw-Hill, Boston, MA

Zeithaml, V. A., Bitner, J. M., \& Gremler, D. T., (2009). Services Marketing: Integrating Customer Focus Across the Firm, New York: McGraw- Hill/ Irwin.

Zeithaml, V. A., Bitner, M. J., \& Gremler, D. D. (2010). Services marketing strategy. Wiley International Encyclopedia of Marketing.

Zemke, R., \& Schaaf, R. (1990). The Service Edge: 101 Companies that Profit from Customer Care, Plume Books.

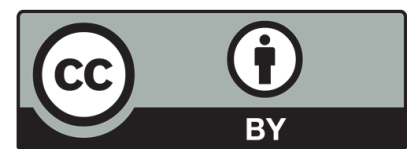

(C) 2016 by the authors; licensee Growing Science, Canada. This is an open access article distributed under the terms and conditions of the Creative Commons Attribution (CC-BY) license (http://creativecommons.org/licenses/by/4.0/). 